\title{
MOHOU BÝT EMOCE VNITŘNĚ MORÁLNÍ?
}

Nad poslední knihou Anthonyho Steinbocka

Nedávno vydaná kniha Anthonyho Steinbocka Moral Emotions: Reclaiming the Evidence of the Heart je významným př́spěvkem k otázkám filosofické etiky. ${ }^{1}$ Autor zde rozvíjí systematický popis vymezené skupiny emocí, totiž takových emocí, které jsou, podle jeho názoru, ze své podstaty morální. Kniha je pozoruhodná přinejmenším ve trojím ohledu. Za prvé zaujme nevšedním soustředěním, s nímž autor vypracovává jemná a velmi bohatá rozlišení v rámci emocionální sféry. Činí tak zcela v původním duchu fenomenologie chápané jako deskriptivní filosofie. Kromě toho kniha obsahuje originální tvrzení, podle něhož jsou některé emoce morální ze své podstaty či přímo. A nakonec je př́íspěvkem k obecně filosofickému chápání osoby. Steinbock uchopuje osobu jako bytost, která se vyznačuje nejen schopností vnímat a racionálně usuzovat, ale také činit zkušenosti emocionálního rázu. Ba co více, Steinbock prohlašuje určitou část emocionální zkušenosti - totiž morální emoce - za určující rys osoby. Následující úvaha se soustředí především na druhý aspekt Steinbockových úvah, totiž na tvrzení o vnitřní morálnosti některých emocí. Předtím je však třeba upřesnit, co chápe pod pojmem emoce, a dále vyjasnit, co ve Steinbockově fenomenologii přesně znamená „morální“.

\section{Definice morálních emocí}

Morální emoce jsou „takové zkušenosti, které spadají do oblastí citů“ a „odhalují..., co znamená být osobou“.2 $\mathrm{V}$ tomto vyjádření můžeme vyzdvihnout tři tvrzení: 1) Emoce je zkušenost, 2) týká se oblasti citů a 3) morální je tehdy, pokud podstatně, a nikoli jen nahodile, odkrývá, „co znamená být osobou“.

1 A. Steinbock, Moral Emotions: Reclaiming the Evidence of the Heart, Evanston 2014. V časopise Reflexe před časem vyšla recenze na Steinbockovu první knihu Home and Beyond. Generative Phenomenology after Husserl, Evanston 1995, viz: M. Pokorný, Dva př́spěvky k systematické fenomenologii, in: Reflexe, 29, 2005, str. $133-139$.

2 A. Steinbock, Moral Emotions, str. 12 a 11. 
Tvrdíme-li, že emoce je zkušenost, má to v kontextu fenomenologického zkoumání přesný význam. U každé zkušenosti lze vyzdvihnout jednak její předmět, a jednak způsob, jak se tento předmět jeví („dává“). Uvedu-li vlastní, nikoli Steinbockův př́klad: Určitou událost - řekněme nečekaný zvuk v setmělé ulici - zakouším jako příznak něčeho, co mne ohrožuje. Způsob, jímž uchopuji tuto událost, může sahat od mírného znepokojení po intenzivní strach. Jinými slovy, ve své zkušenosti vždy chápu něco již v určitém významu (Husserl by hovořil o „uchopování“, Heidegger o „rozumění“ něčemu jako něčemu). Steinbock sám tento obecnější rys fenomenologického př́istupu ke zkušenosti shrnuje slovy: Třebaže fenomenologické př́stupy uchopují zkušenost rozličnými způsoby, všechny přistupují na „dvě metodologické složky, které se týkají toho, ,co' zakoušíme, a toho, ,jak' zakoušíme“.3

Steinbock dále charakterizuje emoce jako zkušenosti, které „se týkají oblasti citů““. ${ }^{4}$ Je třeba je odlišit jak od aktů poznávání (např. vnímání), tak od soudů. Náš autor zde odkazuje k původně Brentanovu rozlišení, které odděluje tři tř́́dy psychických fenoménů: představy (Vorstellungen), soudy (Urteile) a hodnotící akty libosti či nelibosti (Gemütstätigkeiten). ${ }^{5}$ Steinbock následuje Brentana a Husserla, když tvrdí, že emocionální zkušenost je odlišná od představ (například od vnímání), stejně jako od soudů (např́iklad od domnívání se), ovšem odlišuje se od nich ve chvíli, kdy tvrdí, že emoce nejsou založeny na představách a soudech.

Podle Husserla spočívá emocionální a volní sféra („prožitky zalíbení a znelíbení, hodnocení v každém smyslu, přání, rozhodování se, jednání“) na nižších, zakládajících („fundujících“) vrstvách, totiž právě na představách (vnímání či fantazijní zpř́ítomnění) a soudech. Emocionální a volní sféra je „nesamostatný moment“, který může od konkrétního prožitku též „odpadnout, aniž by to zbývající přestalo být konkrétně úplným intencionálním prožitkem“. 6 Vrátíme-li se k př́íkladu náhlého zvuku v setmělé ulici, můžeme jej v souladu s tímto pojetím chápat tak, že náš více či méně intenzivní strach předpokládá zaslechnutí zvuku i soud,

3 Tamt., str. 18: „two methodological components concerning the ,what ${ }^{6}$ and the ,how" of the experience".

4 Tamt., str. 12. Dále odlišuje city (feelings) od afektů (affects), viz str. 12 a 16.

5 Viz např. F. Brentano, O pưvodu mravního poznání, přel. M. Hartl, Praha 1993, str. 26 n.

6 E. Husserl, Ideje $k$ čisté fenomenologii a fenomenologické filosofii, přel. A. Rettová - P. Urban, Praha 2004, § 95. 
jímž zvuku přisoudíme status projevu blížícího se nebezpečí. Teprve na základě toho je myslitelný náš strach. Strach je „,nesamostatný“, závislý na vnímání zvuku a na soudu o nebezpečí, zatímco v opačném směru vztah závislosti nenastává (snad můžeme vnímat nebezpečí zcela bez emocí, jistě je však můžeme vnímat s docela jinou emocí). Podobně lze toužit po horké kávě, již před sebou vidíme, jen díky vjemu kávy, z níž stoupá pára, a soudu, že je horká.

Když Steinbock odmítá chápat zkušenost jako na sobě vystavěné vrstvy intencionálních aktů, z nichž nižší jsou základem pro vyšší, vedou jej v zásadě dva důvody. Za prvé lze dobře ukázat, že emocionální zkušenost ve svém svérázu není vysvětlitelná odkazem k vnímání a souzení, přesněji že emoce nelze vyložit spojením vjemových a soudových aktů. Poukaz na neredukovatelnou svébytnost emocionální vrstvy však ještě může být začleněn do Husserlovy nauky, jejímž smyslem nebylo připodobnit emoce aktům souzení a vnímání. Rozhodujícím krokem při odmítnutí teorie „fundace“ je až následné tvrzení, že alespoň některé emoce jsou nezávislé na představách a soudech. Nejenže důvěra není „druhem soudu“, naděje není „druhem očekávání“, které by bylo založené na předchozích zkušenostech a na nich založených soudech, ale navíc je důvěra, naděje a obecně sféra morálních emocí samostatná, je schopna vlastní existence (,self-subsistent"). ${ }^{7}$

A nakonec morální jsou jen takové emoce, které odhalují, co znamená být osobou. V úvodních pasážích své knihy Steinbock nabízí předběžnou charakteristiku „osoby“. Pojímá osobu především jako „dynamický pohyb a orientaci, která se projevuje napříč akty, jako to, co se ustavuje a rozvíjí na rovině ducha““. 8 Dodává, že osoba je „přímo meziosobní,

7 A. Steinbock, Moral Emotions, str. 10 n. Toto obecné tvrzení Steinbock posléze zkoumá na příkladech jednotlivých emocí. Např́iklad důsledně odlišuje důvěru od očekávání, že se určitá osoba či věc bude chovat spolehlivě či předvídatelně, viz tamt., str. 198-200, 221 n. Bylo by zajímavé dále promýšlet, co přesně „soběstačnost“" morálních emocí znamená. Steinbock vylučuje možnost, že by mezi představami, soudy a emocemi byl vzájemný vztah (tamt., str. 10), tedy napřr. naděje by působila na vnímání a soudy, a naopak. U analýzy důvěry místy připouští, že očekávání založené na představách a soudech se může překrývat s důvěrou jakožto emocí (,trust and reliability can overlap in particular situations“, str. 200). Ihned ovšem dodává, že důvěra je jiného řádu než spoléhání na předvídatelné chování věcí či osob: spoléhání je zaměřené na praktický výsledek, zatímco důvěra je zaměřena na „nejhlubší dimenze osoby“ (tamt.).

8 „Dynamic movement and orientation that lives through acts, that en-actment which unfolds on the level of spirit", tamt., str. 11. 
podstatně vztažná, není základem sebe samé“. 9 Výklad dynamické povahy osoby, stejně jako jejího meziosobního rázu, náš autor svazuje až s detailním rozborem jednotlivých morálních emocí.

Souhrnem můžeme říci, že morální emoce jsou zkušenosti, které se týkají oblasti citů (jakožto odlišných od představ a soudů), přesněji takových citů, které jsou podstatně meziosobní. Podle Steinbocka lze u řady emocí, například u zhnusení či údivu, říci, že mohou být jak meziosobní, tak nikoli, v závislosti na svém předmětu. ${ }^{10}$ Údiv či znechucení mohou být vyvolány jak osobou, tak věcí. Naopak morální emoce jsou podstatně, tedy vždy vztažené k osobám.

Nejrozsáhlejší část Morálních emocí je věnována podrobné a originální analýze jednotlivých emocí, které autor člení do tř́ skupin: „emoce sebe-danosti“, „emoce možnosti“ a „,emoce jinakosti“. Pod souhrnným označením „emoce sebe-danosti“ Steinbock rozebírá pýchu, stud a vinu. Mezi emoce možnosti řadí lítost, naději a zoufalství. Pod hlavičkou emocí jinakosti nakonec analyzuje důvěru, lásku a pokoru. Kromě této klasifikace morálních emocí Steinbock sleduje, jak se jeden druh emoce může přerodit v jiný. Např́iklad stud může být „tvưrčí odpovědí“ na pýchu, ${ }^{11}$ důvěra jakožto postoj, v němž se důvěrující jedinec vztahuje ke druhému a činí sebe sama snáze zranitelným, vylučuje pýchu a může přecházet $\mathrm{v}$ emoce, jako jsou pokora či láska. ${ }^{12}$ Jedna $\mathrm{z}$ nejsilnějších stránek Steinbockovy knihy tkví právě v systematickém rozboru vztahů mezi jednotlivými tř́́dami emocí a v popisu možných emocionálních přerodů. V těchto pasážích jeho kniha překračuje rámec statické fenomenologie a stává se fenomenologií genetickou. ${ }^{13} \mathrm{~V}$ následujícím výkladu musím od těchto bohatých souvislostí odhlédnout. Omezím se na Steinbockovu srovnávací (a statickou) analýzu pýchy. Předtím je však nutné upřesnit, v jakém smyslu Steinbock mluví o emocích „morálních“.

9 „Directly interpersonal, intrinsically relational, and not self-grounding“. Tamt., str. 12.

10 Tamt., str. 14, 196.

11 Tamt., str. 97, 99.

12 Tamt., str. 222.

13 K hlavním zdrojům „genetické fenomenologie“ patři Husserlovy Analysen zur passiven Synthesis (Husserliana, 11), vyd. M. Fleischer, Haag 1966. Anthony Steinbock je překladatelem a vydavatelem anglické verze těchto přednášek, k níž napsal obsáhlý úvod do Husserlovy genetické fenomenologie: E. Husserl, Analyses Concerning Passive and Active Synthesis: Lectures on Transcendental Logic, přel. A. Steinbock, Dordrecht 2001. 
Emoce lze dle našeho autora považovat za morální proto, že „vyjadřjuí vztahy osoby k jiné osobě““. ${ }^{14} \mathrm{~V}$ tomto, dosti neobvyklém, způsobu užití by termín „morální“ nakonec znamenal zhruba totéž co „meziosobní“. Při bližším přihlédnutí však zjistíme, že uvedená dvě adjektiva se nekryjí: „morální význam emoce lze posoudit podle toho, jak otevírá či uzavírá meziosobní vztah. "15 Podle této formulace není výraz „morální“ převoditelný bez dalšího na „meziosobní“, nebot' morální na „meziosobním“ vztahu vyzdvihuje něco dalšího: Umístuje „meziosobní“ na dynamické stupnici sahající od „otevřenosti“ po „uzavřenost“ tohoto vztahu. Steinbock tuto škálu, na níž se zkušenost může nacházet, často spojuje s poukazem na vertikální rozměr osoby a zřetelně jej odlišuje od rozměru horizontálního. Zatímco v „horizontálním“ směru můžeme chápat osobu jako samostatnou bytost, která vstupuje do vztahů s jinými partnery, ve „vertikálním“ směru lze osobu chápat jako nesamostatnou, jako bytost, která není základem sebe samé (not self-grounding). Morální emoce jsou takové zkušenosti, které odkrývají (či zakrývají) ne-založenost osoby, odhalují (či zakrývají), že mezi-osobní vztahy nejsou něčím, do čeho osoba vstupuje jako jeden rovnocenný člen, ale něčím, co je „pod ní“ jako její základ. Pojem ,etika“ Steinbock omezuje na „horizontální“ rovinu zkušenosti (jako př́klad slouží „etika komunikace“), a vyhrazuje adjektivum „morální“ pro „vertikální“ rozměr. ${ }^{16}$

Protiklad, který se vztahuje k vertikálnímu rozměru - totiž protiklad mezi otevřeností a uzavřeností -, prozrazuje, že Steinbock předpokládá určitou představu o dobru, aniž by ji chtěl explicitně formulovat. Je to dáno důrazem na deskriptivní ráz jeho výzkumu emocí, díky němuž se zdráhá charakterizovat „dobro“ na obecné rovině a formulovat nějaký universální pojem „dobra“. Upřednostňuje rozbory, které zpřístupní dobro na př́ípadě jednotlivých emocí, a tím přispějí k tomu, aby se ukázalo. Sledujme toto fenomenologické ukazování na případě pýchy.

14 A. Steinbock, Moral Emotions, str. 14.

15 „The moral tenor of the emotion can be weighed according to how it opens up or closes down the interpersonal nexus." Tamt.

16 Tamt., str. 13 n. Vertikálnost navíc Steinbock spojuje s ne-relativním (absolutním) postavením takto závislé osoby, přičemž náboženské konotace ,vertikálnosti“ jsou nejen nepřeslechnutelné, ale přiznané. Viz též A. Steinbock, Phenomenology and Mysticism: The Verticality of Religious Experience, Indiana and Bloomington 2007, str. $242 \mathrm{n}$. 


\section{Pýcha, sebeláska a př́buzné fenomény}

Steinbock považuje pýchu za podstatně meziosobní, a tedy morální emoci. To může působit překvapivě, nebot' $v$ jeho pojetí pyšný jedinec vylučuje ostatní z uznání, které si vyhrazuje pouze on sám. Nicméně toto vyloučení druhých předpokládá jejich přítomnost, vždyt' pyšná osoba považuje samu sebe za „první mezi ostatními“. ${ }^{17}$ Mezi Steinbockem uváděnými př́íklady pýchy najdeme patriarchát (,,kdy muži vydělávají na spoluúčasti žen") či mýtus spjatý s ideálem úspěšného člověka, který se sám vyšvihl (self-made man). Prvním znakem pýchy je dvojí pohyb „sebe-zdůrazňování a předpokládání druhých právě skrze jejich vyloučeni'“. ${ }^{18}$ Druhým znakem pýchy je její zastírající povaha. Podle našeho autora není pýcha zkušeností, v níž by se osoba sama sobě odhalovala. Pýcha zastírá podstatný rys lidské osoby jakožto osoby, „zastírá meziosobní rozměr Mne sama“. ${ }^{19}$ U pýchy je za třetí důležitý způsob, jakým může dojít k její změně, což Steinbocka pochopitelně zajímá i u ostatních zkoumaných emocí. Označuje pýchu jako postoj (attitude), jímž jedna osoba vylučuje druhé (což znamená, že je předpokládá), a zároveň zastírá meziosobní podstatu svého vlastního osobního bytí. Jakkoli je pýcha něčím, co sami konáme (pride is freely enacted), ${ }^{20}$ nemůžeme od ní sami upustit. Pýcha je svéhlavá či neoblomná (stiff-necked) ${ }^{21} \mathrm{v}$ tom smyslu, že pouhé vědomí o vlastní pýše nepřivodí změnu postoje. Možná změna, překonání pýchy, je „něčím, co nemohu vykonat já“ (something I cannot perform). Jeho zdrojem jsou odlišné morální emoce, které zahrnují „odlišné emocionální akty a zkušenosti“, totiž takové, které jsou orientovány vůči jinému (other-oriented), jako je „důvěřování, milování, pokora, či dokonce emoce sebe-danosti, jako jsou stud a vina“.22

Jakkoli Steinbock poukazuje na zkušenosti orientované vůči jinému a na jejich potenciál čelit pýše, nesměřuje tím k filosofii vyzdvihující „naprosto jiné““.23 Je to patrné např́iklad na jeho srovnání pýchy a sebe-

17 A. Steinbock, Moral Emotions, str. 32 n., 47.

18 Tamt., str. 34.

19 Tamt., str. 48, 52. Aby vyzdvihl meziosobní povahu ,já“, nepoužívá pro ně Steinbock výraz „Self“, ale „Myself“, jenž má podtrhnout, že sebe - jakožto osobu - zakouším tehdy, když se ke mně někdo obrátil, at' už v aktu důvěry či nenávisti.

20 Tamt., str. 66.

21 Tamt, str. 35, viz též str. 66.

22 Tamt., str. 51, viz též str. 99.

23 Tamt., str. 50. 
lásky. Sebelásku řadí mezi emoce orientované vůči jinému, jež mohou vést k omezení či překonání pýchy. Sebeláska se stejně jako každý jiný druh lásky vztahuje k osobě jakožto dynamické bytosti. Láska je otevřená „,vůči možnostem milované či milovaného, které nelze dopředu předjímat a které se mohou vyjevit pouze v pohybu milování. Láska je otevřením se vůči nekonečnu“. ${ }^{24}$ Ryzí sebeláska, nakolik je zvláštním druhem lásky, nemůže být statická, nebot' „se zaměřuje na to, aby se milovaný či milovaná plně utvářeli v souladu se svými možnostmi“. ${ }^{25}$ Existuje dokonce imperativ lásky - „Já ,musím“ milovat sebe sama“ (I „must“ love Myself) -, k němuž neexistuje protějšek na straně pýchy. Původem tohoto imperativu je sama povaha osoby, jíž jsem, totiž v hlubokém smyslu meziosobní a dynamická bytost. Zde má svůj původ „vnitřní normativita“ lásky. ${ }^{26}$ Pýcha tedy nejen zastírá, kým jsem jakožto osoba (totiž že jsem podstatně meziosobní), ale omezuje mne samotného, nebot' není otevřená vůči možnostem, které jsou pro mne zatím neznámé, a které tedy nemohu předjímat.

Steinbock srovnává pýchu nejen se sebeláskou, ale i jinými emocemi, které bychom mohli s pýchou mylně zaměnit. Odlišuje ji od príípadu, kdy jsme „pyšní na něco“ (being proud of, taking pride in). V př́padě pýchy jsem já sám tím, na čem leží hlavní důraz, zatímco jsem-li pyšný na něco, odvozuji svou emocionální zkušenost od něčeho jiného. Toto jiné at' už jde o jednání, událost či vlastnost - může být hodnotné nezávisle na tom, zda na to jsem pyšný. Steinbock považuje např́iklad „gay pride“ za př́ípad, kdy je dotyčná osoba ,pyšná na něco“. Být na něco pyšný či řekněme pro odlišení - hrdý tak může být formou opodstatněné sebeúcty a nikoli pýchy.

Pýcha jakožto morální emoce tedy má sama o sobě určitou morální hodnotu, která je negativní. To jen dokládá, že Steinbock implicitně

24 Tamt., str. 58. Zde se zjevně nabízí otázka, v jakém smyslu je sebeláska vztahem k sobě (milováním sebe), když je vztahem k jinému. U Steinbocka je pozitivním emocionálním vztahem $\mathrm{k}$ tomu, co v sobě samém neznám a nemohu předvídat. Ovšem jak vysvětlíme, že je tento vztah k tomu, co je pro mne neznámé, sebevztahem? Steinbock zde musí předpokládat ještě jiné ,jáa“. Na jednom místě připouští „sebe-vědomí v minimálním smyslu“, jak je rozpracovává ve svých úvahách Dan Zahavi, jako předpoklad svého „robustnějšího“ pojetí já (tamt., str. 12). Otázku, jak se k sobě vztahuje „minimální já“ a „robustnější jáa, však už dále nesleduje.

25 To je jistě volný překlad obtížného obratu: „oriented to the fullest possible becoming of the beloved“. Steinbock dodává: „While self-love is open as the person changes, pride is either a resistance to such dynamism or is a subjectively arbitrary alteration." Tamt., str. 59, viz též str. 224-231.

26 Tamt., str. 268. 
pracuje s určitou představou o dobru: „pýcha je ... morálně negativní. A sice nikoli proto, že by byla podle předepsaných norem ,špatná', ale kvůli tomu, že smršt'uje pole meziosobní zkušenosti ve prospěch vlastního vyniknutí." 27

Jakkoli je pýcha emocionální zkušeností či postojem, který je uzavřený a zastírající, kritika pýchy je myslitelná a její překonání možné. Ovšem je možné nikoli na základě nějakého racionálního principu, nýbrž na základě jiné morální emoce:

„pýcha ... zastírá meziosobní rozměr já jakožto Mne [já v akuzativu, totiž já podstatně meziosobní]. Zde se naznačuje kritika pýchy, která má normativní váhu, ovšem je to taková kritika, kterou umožňují protichůdné zkušenosti v rámci zkušenosti samé, jako je stud, vina, lítost a pokora, kritika, která není ukládána ani abstraktními normami, ani vázaností nějakým racionálním principem.“28

Některé z morálních emocí se tedy ukazují jako vnitřně dobré, ba dokonce jako normativní. Toto tvrzení, stejně jako komparativní popis pýchy a sebelásky, předpokládá, že emoce mají různou hodnotu. Nelze z toho usoudit, že pýcha je, pro Steinbocka, morálně špatná, zatímco láska je morálně dobrá? Z jeho fenomenologie morálních emocí vyplývá nejen to, že „některé emoce jsou prímo morální“ ${ }^{29}$ ale navíc, že existují rozdíly ve vnitřní morální hodnotě emocí samých.

\section{Otázka morální relevance emocí (Aristotelés, Ricœur)}

Mohou však být emoce samy o sobě morální (jako např́klad láska či pokora)? Mohou být některé z nich morální více, a jiné méně? Mohou být některé samy o sobě a vždy morálně špatné (jako např́klad pýcha)? Abychom tyto otázky mohli posoudit $\mathrm{v}$ širších souvislostech, připomeneme odlišný pohled, s nímž se v dějinách myšlení často setkáváme a podle něhož rozhodující etický či morální fenomén nespočívá v emocích samotných. Předtím se však chci velmi stručně a v obecné poloze vrátit k otázce vymezování emocí.

27 Tamt., str. $36 \mathrm{n}$.

28 Tamt., str. 268. Viz též str. 13.

29 Tamt., str. 6. 
Pokus o vymezení emocí se může opřít o jednoduchý postřeh: Emoce souvisí se skutečností, že jsme něčím pohnuti. Smutná událost vyvolá lítost či soucit. Nebezpečí, které se objeví v našem bezprostředním okolí, probudí strach a přiměje nás, abychom se pokusili nebezpečí uniknout nebo mu čelit, přičemž ani jedno, ani druhé chování není neutrální či nezaujaté. V uvedených př́kladech je vždy prrítomno něco, co nás přepadá či zasahuje. Emoce souvisí s tím, že námi něco hýbe. V emocionálním pohnutí je počátek naší aktivity mimo nás samé. První postřeh, podle něhož jsme v emoci ,pohnuti“, tedy jsme pasivní, je ovšem třeba doplnit: Chování, které je emocí vyvoláno, nemusí být prostým výsledkem emoce. Na tytéž emoce lze odpovídat různými způsoby, navíc táž událost může u různých lidí vyvolat různé emoce: Nebezpečí může probudit jak strach, tak vzrušení. Jakkoli jsme v emocích pasivní, neznamená to, že jsme právě a jen „otroky vášní“.30

Toto dvojí pozorování - v emocích, či dokonce emocemi jsme pasivně zastiženi, a přece jim můžeme čelit více či méně rozváženým způsobem - je výchozím bodem mnoha filosofických pojednání. Stručně zde prripomenu dvě z nich, totiž relevantní pasáže z Aristotelovy Etiky Nikomachovy a Ricœurovy Filosofie vůle I. Tím, co mne přitom zajímá, je kromě vlastní definice emocí právě otázka, zda mohou být emoce př́mo morální.

Když se Aristotelés obrací k tématu emocí či „citư“ (pathé), nabízí nejen obsáhlý výčet toho, co považuje za emoce, ale zároveň dodává, že emoce jako takové spadají pod širší pojem „duševních jevů“. Kromě citů sem patří dále dynameis, totiž „vrozené schopnosti“ být náchylní k určité emoci, a dále hexeis, dispozice. „City,“ praví Aristotelés ve svém výčtu, „myslím žádost, hněv, strach, smělost, závist, radost, lásku, nenávist, touhu, žárlivost, soustrast, zkrátka všechno to, s čím jest spojena libost nebo nelibost. “"31 Rozhodující otázka zní, zda jsou lidé považováni za dobré či špatné na základě toho, že zakouší určitou emoci, či proto, že mají určitou „dispozici“, tedy proto, že vykazují nějakou charakterovou ctnost či nectnost. Aristotelés, jak známo, předkládá několik argumentů ve prospěch druhé možnosti. Tím, co může být předmětem chvály či odsouzení, co může být posuzováno jako morálně dobré či špatné, je způsob, jímž se jedinec staví vůči svým citům, vůči pathé. „Dispozice“ (hexeis) jsou v této kapitole Etiky Nikomachovy definovány

30 W. Shakespeare, Hamlet, akt 3, scéna 2.

31 Aristotelés, Eth. Nic. 1105b21-23 (čes. překl. Etika Nikomachova, přel. A. Kř́iž, Praha 1937, str. 33). 
právě vztahem k emocím: jsou tím, „co působí, že se k citům chováme správně nebo nesprávně“ (hexeis de kath' has pros ta pathé echomen eu ú kakós). ${ }^{32}$ Aristotelés pokračuje: „Např́klad v hněvu se chováme nesprávně, je-li prudký nebo bezuzdný, správně se chováme, zachováváme-li střed, a podobně i v citech ostatních. “33 Je-li tím, co může být posuzováno jako dobré či špatné, způsob, jak se chováme či stavíme vůči citům (pros ta pathé echomen), pak je vyloučené, přinejmenším v Aristotelově pojetí etiky, aby emoce byly dobré či špatné samy o sobě.

Otázka, již zde sleduji, není závislá na Aristotelově konceptu hexis. Při její formulaci se můžeme opřít o úvahy bližší Steinbockově analýze, např́klad o fenomenologickou analýzu vůle, již rozvinul Paul Ricœur ve svém raném díle. Emoce námi hýbou, „podněcuji““ naše chtění, navozují naše jednání. Ba co více, není-li naše vůle pohnuta, je neúčinná. Zdroj našeho konání je třeba spatřovat v oblasti emocionálních hnutí. Ricœur to stručně shrnuje slovy: ,vưle ... uvádí tělo do pohybu jen tehdy, když je emocionálně pohnuta." "34 A přesto nás emoce nenutí jednat způsobem, který nám navrhují. Jsou právě a jen ,podnícením jednat““.35 Od samého počátku svého raného díla Ricœur postupně buduje koncepci vzájemného vztahu mezi volním a nevolním momentem lidského chování. V souladu s tím nabízí i „kruhový výklad“ vztahu mezi emocí a činem: „,vášeň', již pasivně zakoušíme, existuje jen pro možnou aktivitu. “36 Neexistuje smutek, údiv či radost bez alespoň rodícího se jednání, které je zarmoucené, udivené či radostné. Z toho vyplývá, že mají-li některé emoce etický význam, může tento význam vycházet najevo pouze ve vztahu k činům, v rodícím se angažování. Morální kvalitu emocí nelze zkoumat pouze popisem emocí samotných. Tímto přesvědčením se Ricœur vymezuje vůči takovým autorům, kteří se domnívali - jako např́íklad Steinbockovi velmi blízký Max Scheler -, že některé emoce samy o sobě vyjevují určité hodnoty. ${ }^{37}$

32 Tamt. 1105b25-26 (čes. př̀kl. str. 33).

33 Tamt. 1105b26-28 (čes. překl. tamt.).

34 P. Ricœur, Filosofie vi̊le I. Fenomenologie svobody, přel. J. Čapek, Praha 2001, str. 267. Viz též str. 295: „Vůle pohybuje jen tehdy, když je emocionálně pohnuta."

35 Tamt., str. 269.

36 Tamt., str. 294.

37 Tamt., str. 86: „Sám se domnívám, že v dané situaci existuje jisté emocionální zjevení hodnot. Max Scheler orientoval svou koncepcí emocionálních a priori etiku odpovídajícím směrem. Domnívám se však, že měl iluzorní představu o autonomii této emocionální intuice vzhledem ke vzmachu mé odhodlanosti, 


\section{Závěr}

Na pozadí předchozích poznámek je patrné, nakolik se Steinbock odchyluje od myslitelů jako Aristotelés či Ricœur, když tvrdí, že „,některé emoce jsou př́mo morální“. V rámci Aristotelova či Ricœurova pojetí emocí, kde jsou emoce pathé, vưči nimž se musíme nějak chovat, případně ne-volní složkou našeho života, která podněcuje naši vůli, nelze představu o bezprostředně morální povaze (některých) emocí hájit. Jak u Aristotela, tak u Ricœura netkví vlastní morální fenomén v emocích samých, ale ve způsobu, jak se díky svému dobře či špatně utvořenému charakteru vůči svým emocím stavíme (pros ta pathé echomen), či ve způsobu, jímž převezmeme emoce coby hybné síly našich činů.

Když Steinbock tvrdí, že některé emoce jsou ze své podstaty morální, nejedná se pouze o odlišný postoj k otázce vnitřní kvality emocí, ale o odlišný náhled na to, co emoce vůbec jsou. Steinbock nechápe emoce jako trpné stavy (pathé), ale v širokém smyslu jako zkušenosti, či dokonce jako postoje (attitudes). Tím se naše otázka přesouvá $\mathrm{k}$ samotnému vymezení emocí. Steinbock uchopuje emoce v kontextu fenomenologické úvahy jako zkušenosti, a tedy u nich lze rozlišit - slovy našeho autora -, „co“ zakoušíme, a ,jak“ to zakoušíme. Díky tomu lze říci, jak jsme naznačili úvodem, že emoce nejsou pouze pasivní stavy. Jakkoli nás při emocionální zkušenosti něco přepadá (náhlý a neobvyklý zvuk), zakoušíme to jako něco, jako více či méně vážné nebezpečí. Je nicméně otázkou, jak tuto aktivní či spontánní složku, díky níž emoce přesahují pouhou pasivnost, popíšeme. Přihlédneme-li ke Steinbockovu pojednání o pýše, sebelásce a př́ibuzných emocích (např̀. hrdosti), vidíme, že rozšiřuje pojem emoce daleko za hranice pouhé pasivity. Podobně i v naději, již rovněž řadí mezi morální emoce, spatřuje Steinbock ,aktivitu“ zaměřenou do budoucna. ${ }^{38}$ Tato aktivita se upíná $\mathrm{k}$ budoucímu stavu, který sama nemůže přivodit, je tedy spíše ,zakoušeným angažováním“ (engagement) ${ }^{39}$ než jednáním. Steinbock charakterizuje naději z časového hlediska jako trpělivost či ,vytrvalé očekávání“ (awaiting-endurance). ${ }^{40}$ I v tomto př́padě je emoce mnohem více než jen pasivitou. Je vytrva-

tj. vzhledem k faktickému rozvrhu. Z téhož důvodu si činil iluze o možnostech čisté etiky ... tato emocionální intuice ... je podřízena zvláštní podmínce a ta ji činí neobvyklou. Hodnoty se mi jeví v té míře, v níž jsem loajální, tedy v níž se jim aktivně zasvěcuji.“

38 A. Steinbock, Moral Emotions, str. 163.

39 Tamt., str. 171.

40 Tamt., str. 175. 
lým postojem. Tím, že Steinbock v různých ohledech rozšiřuje pojem emoce, vystavuje se riziku, že pojem emoce v jeho pojetí ztratí zrretelné kontury. Na jedné straně platí, že emoce zahrnují určitou aktivní složku (totiž - přinejmenším v případě pýchy - postoj), ale na druhé straně jsme emoci vydáni a nemůžeme ji změnit (pýcha je neoblomný postoj, a jeho překonání je „něčím, co nemohu vykonat já“). Pojetí emoce jakožto mé aktivity (postoje), který nicméně nemohu změnit já sám (nebot' je „stiff-necked"), si vyžaduje další vyjasnění. ${ }^{41}$ Je možné, že zde neúměrně zobecňuji př́klad pýchy. Ovšem zásadní otázka zůstává: Jak blíže uchopit emoci jakožto mající zároveň spontánní i pasivní složku? Je spontánnost emocionální zkušenosti přiměřeně vystižena tím, že ji prohlásíme za „postoj“ či ,aktivitu“? Nepřešli jsme tím nepozorovaně od filosofické analýzy emocí k filosofické analýze (emocionálně nabitého) jednání?

Emoce byly $\mathrm{v}$ dějinách filosofie často chápány jako dobré či špatné díky vztahu $\mathrm{k}$ něčemu jinému. ${ }^{42}$ Při jejich posuzování se můžeme např́klad tázat, zda a jak přispívají $\mathrm{k}$ tomu, že náš život jako takový je dobrý. V pojetích tohoto typu jsou emoce hodnoceny ve světle představy o dobrém či št’astném životě (Aristotelés) či ve světle představy o životě jakožto jednotném (viz MacIntyre či Ricœur), ${ }^{43}$ jež nemůže být př́ímo spjata s žádnou jednotlivou emocí. Steinbockovu úvahu o meziosobním svazku můžeme ostatně číst také jako formulování kritéria, v jehož světle můžeme uvažovat o té či oné emoci (zda „otevírá či uzavírá meziosobní vztah") 44 a na základě toho ji posoudit jako morálně dobrou vždy (láska, naděje), jako morálně dobrou pouze př́ležitostně (údiv a znechucení), či

41 Např́íklad se klade otázka, co přesně odděluje toto pojetí emoce od Sartrova Nástinu teorie emocí, kde je emoce účelná, byt' nikoli svobodná činnost. Viz J.-P. Sartre, Nástin teorie emocí, př̀l. J. Čapek, in: J.-P. Sartre, Vědomí a existence, Praha 2006. Steinbockova analýza pýchy některými rysy připomíná to, co Ricœur pojmenovává jako zotročenou vůli, jako chtění, které spoutalo sebe. Ricœur tuto zkušenost ovšem nenazývá emoce, nýbrž „vášeň“, viz P. Ricœur, Filosofie vưle I, str. $33 \mathrm{n}$.

42 Kromě již uvedených autorů můžeme jako další doklad uvést Descartovy Vášně duše, přel. O. Švec, Praha 2002, např. články 41, 45 a 152. K obecnému shrnutí tohoto postoje viz např. Ronald de Sousa, Emotions, in: M. Canto-Sperber (vyd.), Dictionnaire d'éthique et de philosophie morale, Paris 2004, str. 622: „le rôle des émotions, si fondationnel qu'il soit, n'est pas capable d'opérer le tri entre les émotions morales et celles qui ne le sont pas." Viz též str. 626.

43 Viz A. MacIntyre, Ztráta ctnosti. K morální krizi současnosti, přel. P. Sadílková - D. Hoffman, Praha 2004, str. 238-262; P. Ricoeur, O sobě samém jako o jiném, přel. M. Lyčka, Praha 2016, str. 156-224.

44 A. Steinbock, Moral Emotions, str. 14. 
nikdy (pýcha). Steinbock se opakovaně brání tomu, abychom na emoce nahlíželi za pomoci nějakého vnějšího kritéria, at' už by jím bylo například rozlišení rozumové a smyslové stránky lidské zkušenosti, či teorie rozhodování a volby. Odmítá první uvedenou možnost, když vyhlašuje požadavek ,překonat předsudek, podle něhož se lidská osoba vyčerpává dualismem rozumu a smyslovosti"“. ${ }^{45}$ A stejně vyjadřuje určitý odstup od představy, že významným morálním fenoménem je rozhodování a volba: „rád bych se vyvaroval předpokladu, že zde máme co činit s procesem pouhých rozhodování a dilemat.“ 46 Proč presně Steinbock tyto „racionální “ postupy vyloučil ze svých úvah? Snad proto, že mohou být morální jen př́ležitostně, a nikoli „podstatně“ či „přímo“, zatímco některé emoce mohou být, jak praví námi zkoumaná teze, morální „př́ímo“?

Co tedy přesně znamená tato teze? Domnívám se, že můžeme rozlišit dva různé významy. Některé emoce lze považovat za přímo morální za prvé v tom smyslu, že bez dalšího, tj. bez ohledu na okolnosti, vždy a nutně splňují určitá kritéria (otevírají či uzavírají meziosobní vztah). Je-li tomu tak, nic nás ovšem nezavazuje, abychom tato kritéria vztahovali pouze na emoce, a nikoli též na společenská pravidla, činy, charakterové rysy či volby. Pak by platilo, že některé emoce jsou prrímo morální (láska či naděje je vždy morálně dobrá, pýcha je morální, ale nikdy dobrá, údiv a zhnusení jsou morální pouze někdy), ovšem také to znamená, že nejen emoce jsou morální, nebot' morální mohou být i volní akty či společenská pravidla (normy) v té míře, v níž jsou slučitelné s ideou osoby jako nehotové, dějící se, podstatně intersubjektivní bytosti, která není základem sebe samé. Pokud bychom zastávali tento výklad, nemohli bychom bez dalšího odůvodnění odmítat morálku pravidel, fenomény rozvažování, volby či utváření charakteru, vždyt' i ty, jak se domnívám, mohou otevírat či uzavírat meziosobní vztah. Pokud k takovému odmítnutí Steinbock přistupuje, pak proto, že sleduje i jiný, druhý význam „,př́mosti“ morálních emocí: některé emoce jsou morální přímo $\mathrm{v}$ tom smyslu, že jsou samy v sobě zkušenostmi, které nás teprve přivádějí $\mathrm{k}$ objevení osoby, samy jsou v této oblasti zdrojem našich náhledů (,evidencí“). Steinbock by tedy svou tezí o př́mé morálnosti některých emocí tvrdil, že zdrojem morálky jsou vybrané emoce ne jako něco co odpovídá již existujícím kritériím, nýbrž jako zkušenosti, bez nichž nikdy nezjistíme, co znamená být osobou.

45 Tamt.: ,... overcoming the prejudice that the human person is exhausted in the dualism of reason and sensibility.“

46 Tamt., str. 13. 
Nad Steinbockovým výkladem si můžeme klást otázky a přát si, aby autor zřetelněji vyjasnil některé myšlenky: aby více vysvětlil vztah mezi emocemi a jednáním, soběstačnost a oddělenost emocionální sféry, aby podrobněji zdůvodnil vyloučení rozvahy, volby či charakteru z oblasti morálně relevantních dějů. Bez ohledu na to je však třeba ocenit význam knihy Moral Emotions jakožto vysoce originálního a obdivuhodně systematického zkoumání emocionálních zdrojů, které tvoří nezbytnou podmínku bytí osoby. Otázkou ovšem zůstává, zda jsou i podmínkou dostačující. ${ }^{47}$

Jakub Čapek

47 Text vznikl za podpory Programu rozvoje vědních oblastí na Univerzitě Karlově č. 13: Racionalita ve vědách o člověku, podprogram Proměny etiky. 